Article

\title{
Relationship between Maternal and Fetal Resistin Levels in Obesity and Normal to Anthropometry Newborn Babies
}

\author{
Siska Anggraini ${ }^{1}$, Yusrawati $^{2}$, Mayetti $^{3}$ \\ ${ }^{1}$ Program of Magister Midwifery, Faculty of Medicine, Padang,Indonesia \\ ${ }^{2}$ Obstetri Gynecology,RSUP DR M. Djamil,Faculty of Medicine,Padang,Indonesia \\ ${ }^{3}$ Sub Division Emergency Child Hospitalization, RSUP DR. M. Djamil , Faculty of Medicine, Padang,Indonesia
}

\begin{tabular}{|c|}
\hline SUBMISSION TRACK \\
\hline $\begin{array}{l}\text { Recieved: } \\
\text { Final Revision: } \\
\text { Available Online: }\end{array}$ \\
\hline KEYWORDS \\
\hline $\begin{array}{l}\text { Maternal Resistin, Fetal Resistin, } \\
\text { Anthropometry of Newborn, Obesity }\end{array}$ \\
\hline CORRESPONDENCE \\
\hline
\end{tabular}

Phone: 082284345662

E-mail: siskaanggraini832@email.com

\begin{abstract}
A B S T R A C T
Status of excess nutrition (obesity) and less influence on fetal growth. Obesity has increased fat, which increases some adipokines, one of which is resistant. Resistin plays a role in maintaining glucose homeostasis by inducing insulin resistance, antiadipogensis and inflammation. Resistin is found in the baby's umbilical cord so that resistin can play a role in fetal growth. The purpose of this study was to evaluate differences in maternal resistin levels between obese and normal weight mothers and their relationship to anthropometry of newborns. Material and Matode: This research is an observational analytic study with crosssectional design. Subjects consisted of 20 obese mothers and 20 normal weight people. Sampling was done by consecutive sampling at Dr. M. Djamil Padang, dr. Rasidin Padang and TK III Reksodiwiryo Padang Hospital, Indonesia. Blood samples were measured by spectrophotometry. Statistics were analyzed by Mann Whitney U-Test and Spearman Test. Results: Median maternal resistin in obese subjects and normal weight was 1406 (1024.31-1947.78) ng / L and 1308.46 (740.161521.56) ng / L ( p <0.05). Median fetal resistin in obese subjects and normal weight was 1086.47 (820.09-2205.29) ng / L and 1077.59 (704.65-1654.76) ng / L (p>0.05). Conclusion: There was a relationship between maternal resistin and newborn body weight with $r=-0.412(p<0.05)$. There was a correlation between fetal resistin levels with the weight of newborns and infant body length $(r=-0.694$, and $r=-0.455)(p<0.05)$. Resistin levels affect fetal weight gain in the obese and normal weight.
\end{abstract}




\section{INTRODUCTION}

Low birth weight (LBW) are one of the problems in fetal growth. LBW is still the cause of infant mortality. LBW prevalence can reach around $11.2 \%$. One of the factors causing LBW is maternal factors. Maternal nutritional status before and during pregnancy determines the condition of the baby to be born. Poor nutrition and excess nutrition (obesity) will have an impact on fetal growth. Poor nutrition will cause low birth weight or birth defects. Many studies report that obesity causes low birth weight $^{21,29,35}$.

Obesity has increased fat accumulation so that it increases the secretion of some dipokines. Resistin is an adipokine that is found to increase in obesity. In humans, resistin is produced by fat, macrophages, placenta, preosteoblasts and osteoblasts. Resistin has a metabolic function to maintain glucose homoestasis through inflammation, insulin resistance and antiadipogenesis. Resistin has been postulated to play a role in healthy pregnancies, where low levels of resistin play a role in trophoblast cell invasion, angiogenic and increase trophoblast glucose uptake $30,33,27$.

Increased levels of resistin reaching 50-100 ng / mL can inhibit GLUT1 (Glucose Transporter 1) activity through the AMPK pathway. AMPK and GLUT1 bonds play a role in increasing Mamalian Target OfRapamycin (mTOR) activity. This reduced bond can lead to reduced amino acid signaling mediated by $\mathrm{mTOR}^{4}$. Amino acids are important substrates in the formation of neurotransmitters. Neurotrasmitter is a chemical that forms neuron cells that make up the brain. In addition, Resistin also acts as an antiadipogenic so resistin plays a role in the availability of fuel for the fetus ${ }^{29,3,1}$.

Recently the expression of resistin gene is also found in preosteoblast cells and osteoblasts. Resistin plays a role in developing the skeleton by controlling the differentiation of preosteoblast ${ }^{33}$. Resistin is considered a negative factor for bone mass by increasing the number of osteoclasts and activating the NF-kB promoter. Resistin is able to induce TNF- $\alpha$, where TNF- $\alpha$ is a cytokine known as an activator and inhibitor of osteoclastogenesis ${ }^{12,1,10}$. Resistin is found in the baby's umbilical cord so that resistin can play a role in fetal growth. Based on the background above, the researcher was interested in examining the differences in maternal and fetal resistin levels between obese mothers and normal weight and its relationship to anthropometry of newborns.

\section{METHODS}

This study was an observational study with a cross sectional approach conducted from August to November, 2017. The population in this study were all women who gave birth at RSUP dr. M. Djamil Padang, TK III Reksodiwiryo Padang Hospital and dr. Rasidin, Padang, Indonesia. Subjects were obtained by Consecutive Sampling method. The case group was a group of obese mothers (IMT $\geq 30$ ) obtained based on maternal BMI measurements before pregnancy. Meanwhile, the control group is a normal weight mother (BMI 18.5-24.9).

Exclusion criteria were Diabetes mellitus (GDS $\geq 200 \mathrm{mg} / \mathrm{dl}$ ), infants with congenital malformations (microcephaly, macrocephaly, hydrocephalus and analgesia), leukocytes $\geq 16,000 / \mu \mathrm{L}$. After getting information before the study, the subjects who had signed the informed consent were taken blood from the cubital vein before the baby was born. While fetal blood was taken after cutting the umbilical cord on the umbilical cord attached to the placenta. The blood that has been obtained is then analyzed for its serum resistin levels using a Spectrophotometry device at the Biomedical Laboratory of the Unand Medical Faculty.

Data analysis was carried out by testing data normality with Shapiro-Wilk. Analysis of differences in maternal and fetal resistin levels in obese and normal mothers with Mann Whitney test. Correlation analysis to assess the relationship of maternal and fetal resistin levels to 
anthropometry of newborns was used by the Spearman Test.

\section{RESULT}

During the study sample collected were 40 maternity mothers consisting of 20 subjects of the obese group and 20 subjects of the normal weight group. Table 1 shows that the average infant body weight of obese subjects is $3325 \pm 324.27$ and $3374 \pm 233.65$. The results of statistical tests produced no significant differences in the weight of newborns between groups of obese women with normal weight with $\mathrm{p}=0.312(\mathrm{p}>0.05)$.

Table 2 shows that there were no significant differences in infant body length $(p=0.399)$ and infant head circumference ( $p$ $=0.306$ ) between groups of obese women with normal weight. Table 3 shows the levels of resistance in the obese group is 1406 (1024.31-1947.78) ng / L. Whereas the normal weight group obtained maternal resistin levels were $1308.46 \quad(740,16-$ 1521,56). To see the differences in the two groups, the Mann Whitney U-Test was then performed. As shown in table 4, there is a difference in maternal resistin levels between the obese and normal weight groups with $\mathrm{p}=$ 0.021 ( $\mathrm{p}<0.05)$.

Table 5 shows that fetal resistin levels in the obese group were 1086.59 (820.092205.29) $\mathrm{ng} / \mathrm{L}$ andthe normal weight group was 1077.59 (704.65-1654.76) ng / L. After the Mann Whitney U-Test was found there was no difference in fetal resistin levels between the obese and normal weight groups with $\mathrm{p}=0.79(\mathrm{p}>0.05)$.

Table 1. Birth Weight of a Newborn in Obesity and Normal

\begin{tabular}{|c|c|c|c|}
\hline \multirow[t]{2}{*}{ Variable } & \multicolumn{2}{|c|}{ Group } & $\mathrm{p}$ \\
\hline & Obesity & $\begin{array}{l}\text { Normal } \\
\text { weight }\end{array}$ & \\
\hline
\end{tabular}

\begin{tabular}{lccc}
\hline & Mean \pm SD & Mean \pm SD & \\
\hline Birth & $3325 \pm 324,27$ & $3374 \pm 233,65$ & 0,312 \\
Weight Of & & & \\
Newborn & & & \\
\hline
\end{tabular}

Table 2. Body length and infant head circumference in obesity and normal

\begin{tabular}{cccc}
\hline Variable & \multicolumn{2}{c}{ Group } & $\mathrm{p}$ \\
\cline { 2 - 3 } & Obesity & $\begin{array}{c}\text { Normal } \\
\text { Weight }\end{array}$ & \\
\cline { 2 - 3 } & $\begin{array}{c}\text { Median(Min } \\
\text {-Max) }\end{array}$ & $\begin{array}{c}\text { Median(Min } \\
\text {-Max) }\end{array}$ \\
\hline $\begin{array}{c}\text { Body } \\
\text { lenght }\end{array}$ & $49(47-51)$ & $49(47-51)$ & 0,399 \\
\hline Head & $33,00(32-$ & $33,00(33-$ & 0,306 \\
$\begin{array}{c}\text { Circumfer } \\
\text { ence }\end{array}$ & $35)$ & $35)$ & \\
\hline
\end{tabular}

Table 3. Differences in Maternal Resistin Levels in Obesity and Normal Mothers

\begin{tabular}{lccc}
\hline Variable & $\begin{array}{c}\text { Obesity } \\
\text { Median (Min-Max) }\end{array}$ & $\begin{array}{c}\text { Normal Weight } \\
\text { Media(Min-Max) }\end{array}$ & $\mathrm{p}$ \\
\hline $\begin{array}{l}\text { Maternal } \\
\begin{array}{l}\text { Resistin } \\
(\mathrm{ng} / \mathrm{L})\end{array}\end{array}$ & 1406 & 1308,46 & 0,021 \\
& $(1024,31-1947,78)$ & $(740,16-1521,56)$ & \\
\hline
\end{tabular}

\section{Table 4. Differences in Fetal Resistin Levels in Obesity and Normal Mothers}

\begin{tabular}{lccc}
\hline Varible & $\begin{array}{c}\text { Obesity } \\
\text { Median (Min-Max) }\end{array}$ & $\begin{array}{c}\text { Normal Weight } \\
\text { Median(Min-Max) }\end{array}$ & $\mathrm{p}$ \\
\hline $\begin{array}{l}\text { Fetal } \\
\text { Resistin } \\
(\mathrm{ng} / \mathrm{L})\end{array}$ & 1086,47 & 1077,59 & 0,79 \\
& $(820,09-2205,29)$ & $(704,65-1654,76)$ & \\
\hline
\end{tabular}

Then the Spearman test was conducted to assess the relationship between maternal and fetal resistin levels to anthropometry of newborns. As shown in Figure 1 where there is a relationship between maternal resistin and birth weight of newborns with a negative pattern with a value of $\mathrm{r}=-0.412, \mathrm{p}=0.008$ ( $p<0.05)$. This shows that the decreasing 
level of resistin will be followed by an increase in the weight of the newborn. Figure 2 shows that there is no correlation between maternal resistin level and newborn body length with $p=0.665$ ( $p>0.05$ ), $r=-0.071$. Figure 3 shows that there is no relationship between maternal resistin levels and newborn head circumference. with a value of $p=0.236(p>0.05), r=-0.192$.

\section{Figure 1. Relation of Maternal Resistin Levels to Newborn Weight}

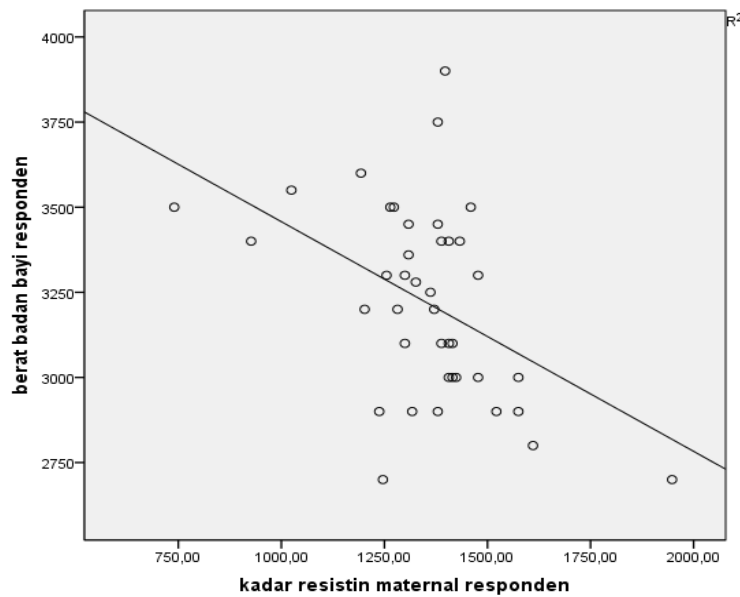

Figure 2. Relationship of Maternal Resistin Levels with Body Length of Newborns

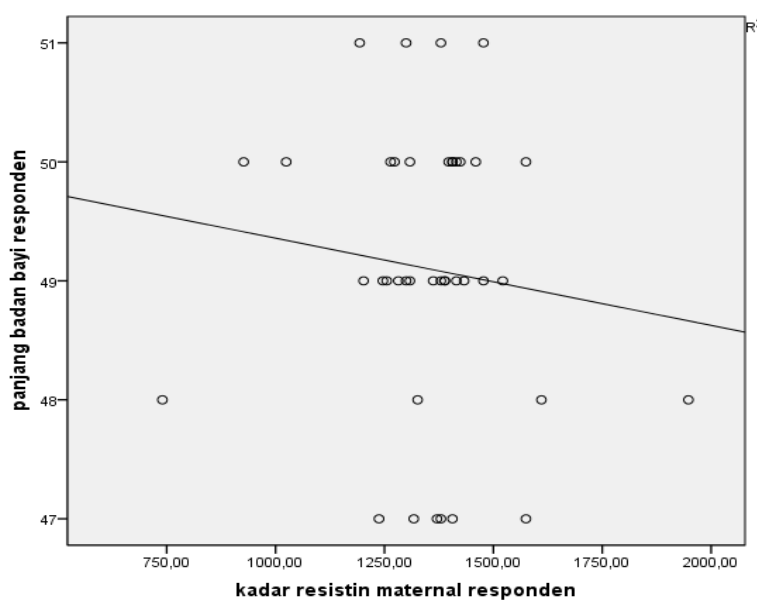

Figure 3. Relationship between Maternal Resistin Levels and Newborn Head Circumference

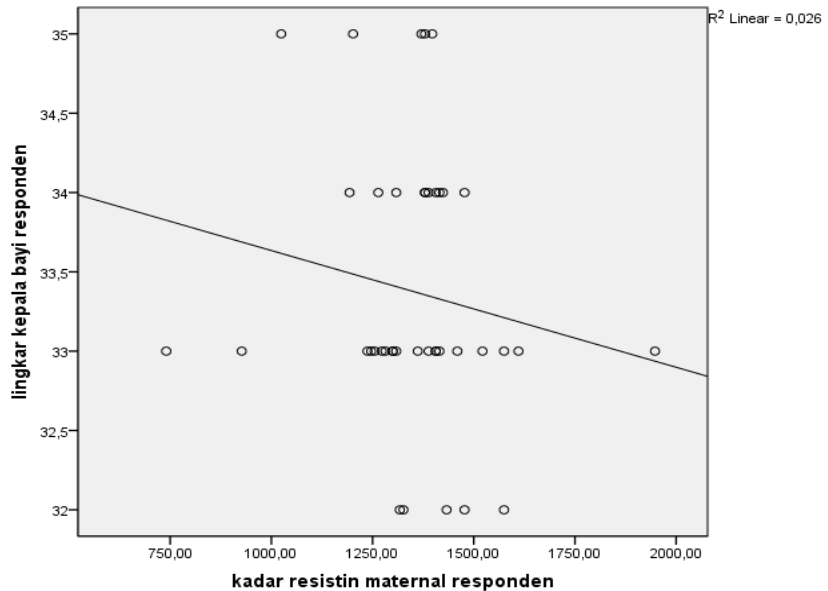

The results of the Speraman test to assess the relationship between fetal resistin to anthropometry of newborns showed that there was a correlation between fetal resistin levels with newborn and body weight of newborn babies as shown in Figure 4 and Figure $5(\mathrm{p}=0,000(\mathrm{p}<0,05), \mathrm{r}=-0,649)$ and $(\mathrm{p}=0.003(\mathrm{p}<0.05), \mathrm{r}=-0.455$.). Figure 6 shows that there is no correlation between fetal resistin level and newborn head circumference with $\mathrm{p}=0.814(\mathrm{p}>0.05), \mathrm{r}=$ 0.03 .

Figure 4. Relationship of Fetal Resistin Levels with Newborn Babies Weight

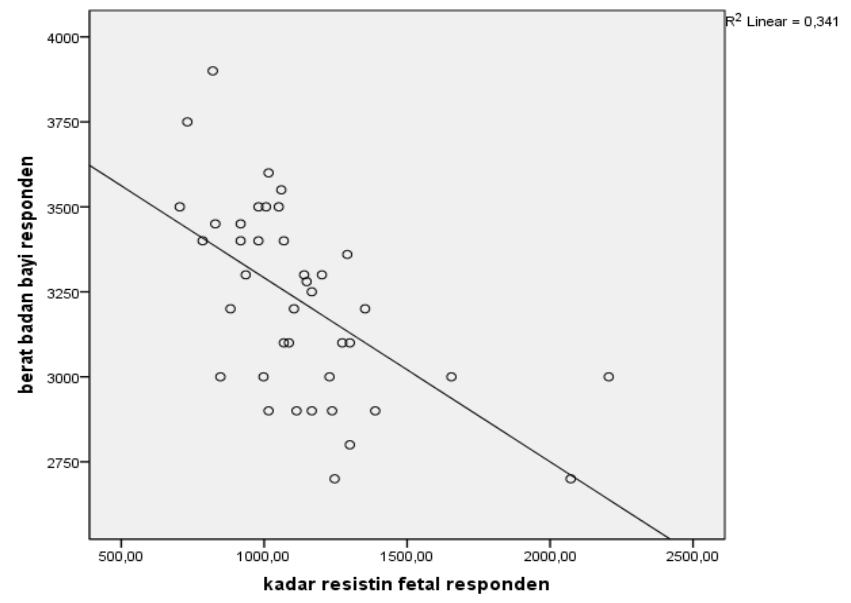

Figure 5. Relationship of Maternal Resistin Levels with Body Length of Newborn Babies 


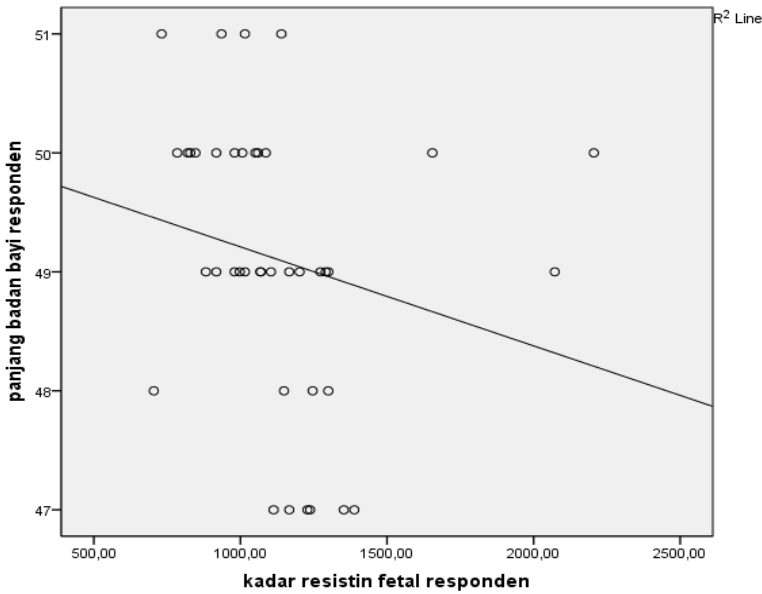

Figure 6. Relationship between Fetal Resistin Levels and Newborn Head Circumference

\section{DISCUSSION}

In this study, it was found that the median level of resistin in the group of obese mothers was higher than in the normal weight group. Analysis showed that there were differences in maternal resistin levels between obese women with normal weight and $\mathrm{p}=0.021(<0.05)$.

The results of this study are same with result ofHyeong and Ahima, 2013 who found that resistin levels were found to be higher in obesity than non-obese and had a positive correlation with the area of body mass index (BMI) and visceral fat area. Resistin is an adipokine that was first discovered in fat cells ${ }^{15}$. Resistin in normal pregnancy is found with a range of levels of $0.70-22.34 \mathrm{ng} / \mathrm{mL}^{23}$. Different studies found by Jyh et al (2007) found that plasma resistin levels were higher in pregnant women than non-pregnant women. Danqing et al (2005) found it different that differences in resistin levels during pregnancy were only in the

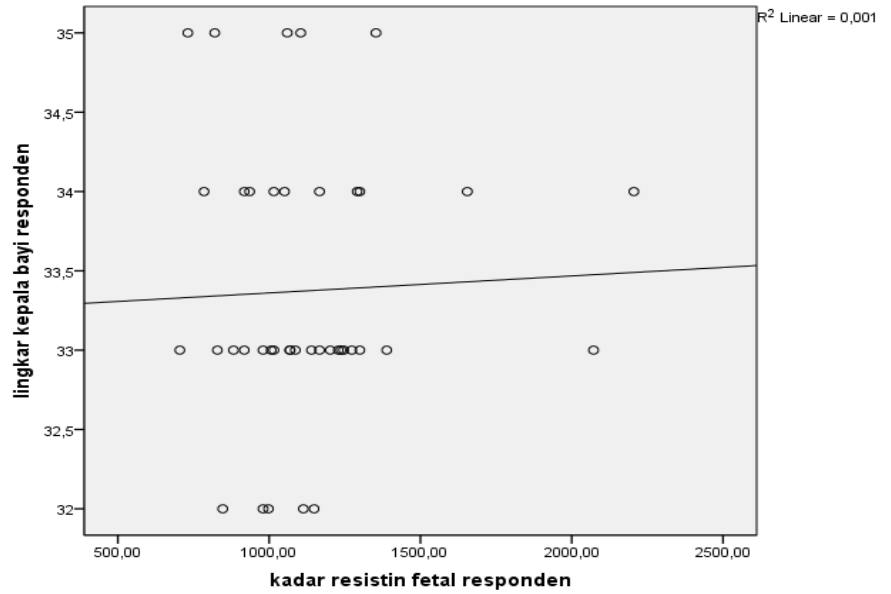

third trimester and were higher than in nonpregnant women and BMI did not affectto resistin levels during pregnancy.

In this study researchers found a difference in maternal serum resistin levels between obesity and normal weight. The difference with previous studies was caused by differences in the characteristics of the sample and the research method. Research conducted by Marfianti (2006) found that resistin levels were higher in obese patients with insulin resistance than obesity without insulin resistance which was carried out by HOMA-IR index assessment. Obesity is at risk for insulin resistance due to an increase in inflammatory factors in the body. Resistin increases inflammation by inducing several proinflammatory cytokines such as TNF- $\alpha$ which can inhibit IRS1 so that it interferes with GLUT4 in glucose uptake to cells which leads to insulin resistance.

There are differences in the method of this study with previous studies where Vernini et al (2016) used the Oral Glucose Test Tolerance (OGTT) method to assess the 
condition of prediabetes which also affects the increase in resisitin levels. There is a difference between examining impaired glucose tolerance and plasma glucose. Various studies have shown that impaired glucose tolerance is more associated with moderate insulin resistance. Fasting plasma glucose is more associated with a deficit in insulin secretion. Insulin resistance is the basis for the onset of impaired glucose tolerance. Resistin can induce insulin resistance. So that the condition with insulin resistance can be started with an increase in plasma resistin levels ${ }^{28,31,2}$.

In this study there were no differences in fetal resistin levels between obese and normal weight mothers. Although higher resistin levels were found in obese mothers than normal weight mothers but did not affect the baby's weight in this study. Different research results were found by Geum et al (2006) that there were differences in mean maternal and umbilical serum resistin levels $(21.34 \pm 1.07 \mathrm{ng} / \mathrm{ml})$ which were significantly higher than maternal serum resistin levels $(10.13 \pm 1.12)$. Jing, et al. (2010) found low resistin levels in macrosomia babies' umbilical cord samples compared to SGA infants and positively correlated with maternal resistin. Different results of the study were also stated by Pak Cheng et al (2006) that serum resistin levels in term infants were higher than preterm and were higher than maternal serum and correlated with maternal serum resistin.

The difference between this study and previous research may be due to differences in research methods and characteristics of the sample in the study. Simone, et al (2009) found that dexamethasone can reduce resistin levels in the placenta. In addition, estrogen and progesterone are also thought to be able to influence placental resistin levels. Giving estrogen and progesterone can reduce the placental resistance level in vitro. Dexamethasone, estrogen and progesterone are groups of glucocorticoids that act as antiinflammatory. The association of glucocorticoids with the nucleus receptor complex can influence the transcription of a number of target genes which causes a decrease in the synthesis of proinflammatory molecules including cytokines, interleukins, adhesion molecules and proteases. Researchers assume that estrogen and progesterone produced by the placenta can reduce levels of resisitin in the umbilical. This suggests an adaptive response from the placenta that acts as a barrier in pregnancy ${ }^{26}$. Charlier, et al (2008) reported increased chronic inflammation in pre gravida obese mothers affecting intrauterine life with increased accumulation of proinflammatory macrophages and cytokines in the placenta. Robert, et al (2011) found that although the accumulation of proinflammatory macrophages and cytokines increased in the placenta pre gravida obese women were not accompanied by an increase in neutrophil cell populations in the placental villi, and an increase in the neutrophil population mostly in maternal interstitial space.

In this study, the researchers found a negative correlation between maternal and fetal resistin levels with newborn body weight with a value of $\mathrm{p}<0.05$. The same results were also found by Jing, et al (2014) that umbilical resistin levels were negatively correlated with the weight of newborns, infant BMI and placental weight in normal weight infants, macrosomia and Fetal Growth Restriction (FGR).

Resistin has two main metabolic roles. Resistin has the opposite action to insulin which leads to glucose homeostasis. This action ends with a whole or partial 
increase in glucose levels mediated by the AMP-activated protein kinase pathway, thereby increasing the enzyme gluconeogenesis in the liver, decreasing the ability of skeletal muscle and adipose tissue to capture insulin mediated glucose. The second role of resistin is antiadipogenic and inhibits the proliferation of 3T-L1 adipocytes $^{9,17}$. Resistin plays a role in adipogenesis. Where resistin can inhibit adipocyte differentiation. Resistin affects the $\alpha$ and $\beta$ Protein Enhancers Binding (C/ $\mathrm{EBP} \alpha$ and $\mathrm{C} / \mathrm{EBP} \beta$ ) which are adipogenic transcription factors. Resistin reduces lipid hatch synthesis by decreasing proteins involved in lipid metabolism during preadipocyte. A decrease in Fatty acid synthase (FAS) and Acetyl-CoA carboxylases 1 and 2 (ACC1 and ACC2) induced by resistin suggests that resistin affects lipid metabolism during adipocyte maturation. Decrease in lipid synthesis reduces fat storage so that resistin contributes to the availability of fuel for the fetus $^{34,9}$. Geum et al (2006) reported that resistin not only plays a role in energy homoestasis but also plays a role in weight control through effective regulation of negative feedback in adipogenesis.

The results of the study found that there was no correlation between maternal resistin levels with the length of the baby's body and the head circumference of newborns with $p \geq 0.05$. Resistin plays an important role in the development of the framework by controlling preosteoblast differentiation. Resistin has a strong effect on osteoclastogenesis by increasing the number of osteoclasts and activating the NF$\mathrm{kB}$ promoter. Thus, resistin is a negative factor for bone mass that is consistent with the study that serum resistin concentrations are negatively correlated with BMD bodies of Chinese men and menopausal women and lumbar spine BMD in adult men ${ }^{33}$.

TNF- $\alpha$ induced by resistin can act as an inhibitor and activator of osteoclastogenesis. In addition, the number and activity of bone regulating cells, namely cells such as OC and OB, one of which can be affected by TNF- $\alpha$ activity. Increased TNF- $\alpha$ inhibits osteoblast differentiation through resistance to IGF1, BMP6 and LMP1 in osteoporosis patients ${ }^{12,1,10}$.

In this study, researchers did not find a significant association between maternal serum resistance levels with newborn body length. However, the researchers found a relationship between fetal resistin levels and the body length of a newborn baby. This shows that fetal resistin levels affect more to body length than maternal resistin levels. This may be due to the many maternal factors that influence calcium absorption and type 1 collagen synthesis. Several factors play a role in bone formation such as genetics, some hormones and cytokines. In addition, calcium absorption is influenced by several factors such as PThRP hormone, estrogen, progesterone, placental lactogen, IGF-13. This suggests that maternal resistin levels may reflect the situation of fetal development in the uterus and have important clinical implications for predicting infant birth weight ${ }^{16}$.

The results of the study found that there was no association between maternal serum resistin levels and fetal resistin levels with newborn head circumference. The same results were found by Vernini, et al (2016) which stated that there was no correlation between maternal serum resistin levels to newborn head circumference but there was a relationship between maternal adiponectin levels on newborn head circumference and ponderal index with leptin levels. The same 
study was found by Fatouhikia, et al (2016) that there was no correlation between the levels of umbilical resistin and the head circumference of newborns with $\mathrm{p}>0.05$.

Adiponectin and resistin have opposite actions. Adiponectin can increase insulin sensitivity, while resistin increases insulin resistance. Glucose is an important substance for fetal metabolism and growth. Brain growth is related to the activity of glucose, protein transporters and GLUT1 expression. So that the role of adiponectin is considered to influence fetal brain growth ${ }^{9,33}$.

\section{CONCLUSION}

1. Increased fat mass (hyperlipidemia) during pregnancy may affect an increase in resistin level during pregnancy which has clinical implications for the assessment of fetal weight.

2. Further research can be conducted to assess the relationship between levels of resistin to weight gain during pregnancy using the Cohort Study approach.

3 . It is expected that the results of this study can be used as input for the Health Office in examining maternal resistin levels which have implications for the assessment of fetal weight.

\section{REFERENCES}

1. Avagliano, L. Garo, C. And Marconi, AM, 2012. Placental Amino Acids Transport In Intrauterine Growth Restriction. Journal Of Pregnancy. Vol. 2012.pp 6.

2. Benomar, Y. Gertler, A. De Lacy, P. Crepin, D. Hamouda, HO. Roffault, L. et $a l$, 2013. Central ResistinOverexpossure induces insuli resistance through TollLike 4 Receptor 4.Diabetes Journal. Vol. 62. pp. 102-144.

3. Blackburn, ST. 2013. Maternal, Fetal \& Neonatal Physiology : A Clinical Perspective. Elsevier.

4. Buller, CL, 2010. Role Of GLUT1 In The Mammalian Target of Rapamycin Pathway: Machanism of Regulation. Dissertation. Molecular and Integrative Physiology University. Michigan.

5. Challier, JC.Basu, S. Bintein, T. Hotmire, K. Minium, J. Catalano, PM. et al, 2008. Obesity in pregnancy stimulates macrophage accumulation and inflammation in the placenta. National Institute Of Health. Vol. 29, no. pp. 274281.

6. Cortelazzi, D. Corbetta, S. Ronzoni, S. Pelle, F. Marconi, A. Cozzi, V. et al, 2008. Maternal And FoetalResistin and adiponecin Concentrations In Normal nad Complicated Pregnancies. Clinical
Endocrinology Queen's Medical Research Institute. Vol. 66. pp. 447-453.

7. Danqing, C. Minyue, D. Qin, F. Jing, HE. Zhengping, W. Xiaofu, Y, 2005. Alterations of serum resistin in normal pregnancy and pre-eclampsia. Clinical Science. Vol. 108. Pp. 81-84.

8. Farid, SD. Najati, N. Gharebaghi, MM. Haghjo, AG. Ghojazadeh M, 2012. Resistin in Cord Blood of Small for Gestation Age and Appropriate for GestationAge Term Neonates. Tehran University Of Medical Science. Vol. 23, no.6. pp 659-663.

9. Lissauer T \&fanaroff A. 2009. At a Glance Neonatologi. Erlangga. Jakarta.

10. Fatouhikia, S. Pourarian, S. Javanmardi, H. Setoodehnia, Z and Saki, F, 2016. Investigating the Association of Cord Blood Resistin and Birth Weight in Term and Preterm Neonates. Journal OfPediatrica. Vol.4(11).pp.3769-75.

11. Fernandez, CM. Acro, AD. Gallardo, N. Aguado, L. Rodriguez, M. Ros, M. et al, 2013. S-Resistin Inhibits Adipocyte Diffrentiation And Increase TNFa Expression And Secretion In 3T3-L1 Cells. BiochimicaEtBiophysicaActa. Vol. 1803. pp. 1131-1141.

12. Fitter, S. Matthews, M.P. Martin, SK. Jianling, X. Soo, S.O. Walkley, C.R. et al, 
2016. mTORC1 Plays an Important Role in Skeletal Development by Controlling Preosteoblast Differentiation. American Society For Microbiology. Vol. 37.

13. Geum, JC. Sang, WY. Soon, CH. MinJeong, OH. Tak, K. Hai, JK. Etal, 2006. Correlations between umbilical and maternal serum resistin levels and neonatal birth weight. ActaObstetriaetGynecologica. Vol 85. Pp. 1051-1056.

14. Gilbert, L. Xiaofei, H. Farmer, P. Boden, S. Kozlowski, M. Rubin, J. et al, 2000. Inhibition Of Osteoblast Differentation By Tumor Necrosis Factor$\alpha$. The Endocrinology Society. Vol.141, no. 11

15. Gaccioli $F$, Lager $S$, Powell $T$, and Jansson T, 2013. Placental Transport in Response to Altered Maternal Nutrition. National Institute Of Health. Vol. 4, no. 2. pp. 101-115

16. Huanbin, H. Liping, $X$. Aimei, W. Jiashi, G. Huihui, K. Yungzhong, Y. Xiaoning, Y, 2016. Correlation of resistin expression in maternal serum and subcutaneous adipose tissue with insulin resistance in gestational diabetes mellitus. Original Article. Vol. 9. No. 9. pp. 18721-18727.

17. Hyeong, KP and Ahima, RS, 2013. Resistin in Rodents and Humans. Revie Obesity and Metabolic syndrome. Diabetic Metabolic Journal Seoul. Vol. 37. pp.404-414.

18. Jing, W. Li-Xin, S. Xing, D. Xin, W. Nan, W. Shu-se, W, 2010. Relationship of adiponectin and resistin levels in umbilical serum, maternal serum and placenta with neonatal birth weight. Australian And New Zealand Journal Of Obstetrica And Gynecology. Vol.50.pp. 432-438.

19. Jyh, KN. Shali, MT. Romero, R. Kusanovic, JP. Erez, O. Gotsch, F. et al, 2007. Resistin : A Hormone Which Induces Insuli Resistance Is Increased In Normal Pregnancy. Perinatology Research. Vol. 35. pp. 513-512.
20. Karatas, A. Issikent, NT. Ozlu, T and Demirin, H, 2014. Relationship of maternal serum resistin and visfatin levels with gestational diabetes mellitus. Gynecological Endocrinology.Vol.30(5).pp. 1473-0766.

21. KementrianKesehatan Indonesia tahun 2015 "RenstraKesehatan Indonesia 20152019” Jakarta.

22. Marfianti, E, 2006. Perbedaan Kadar ResistinPadaObesDenganResistensi Insulin Dan ObesTanpaResistensi Insulin. JurnalKedokteran Dan Kesehatan Indonesia.

23. Megia, A. Vandrell, J. Gutierrez, C. Sabate, M. Brosch, M. Fernandez-Real, JM. et al, 2008. Insulin Sensitivity and Resistin Levels In Gestational Diabetes Mellitus And After Parturition. European Journal Of Endocrinology. Vol. 158. pp. 173-178.

24. Norwood, AK, 2013. Maternal Obesity Alters Fetal Development Due To Impaired Placental Function And Has Lasting Effects On Adult Offspring. Thesis. University Of Nebraska. Nebraska.

25. Noureldeen, A.F. Qusti, S.Y. And Alseeni. M, 2014. Serum Leptin, Adiponectin, Resistin, Visfatin and Inflammatory Cytokines in Normal Weight and Obese Women with Normal Pregnancy and with Preeclampsia. Life Science Journal. Vol. 11. No. 5.

26. Pak-Cheng, NG. Cheuk, L. Christopher, WK. Lam, I. Chan, EW. Tai, F. et al, 2006. Resistin in Preterm and Term Newborns: Relation to Anthropometry, Leptin, and Insulin. Pediatric Research. Vol 58. No.4.

27. Hehai, P. Xiang, L. Jianru, W. Kuibo, Z. Hao, Y. Zerni, L, 2015. LIM Mineralization Protein-1 Enhances Bone Morphogenetic Protein-2-Mediated Osteogenesis Through Activation of ERK1/2 MAPK Pathway and Upregulation of Runx2 Transactivity. JounrnalOf Bone And Mineral Research.Vol 30. No. 8. Pp 1523-1535. 
28. Robert, K.A. Riley, S.C. Reynolds, R.M. Barr, S. Evans, M. Statham, A. et al, 2011. Placental Structure And Inflammation In Pregnancies Associated With Obesity. Elsevier Journal. Vol. 32. Pp. 247-254.

29. Sadler, TW.

(2012).

EmbriologiKedokteranLangman. Edisi 12. Jakarta: EGC.

30. Shaw, J.E. Zimmet, P.Z. Courteen, M.D. Dowsw, G.K. Chitson, P, 1999. Impaired Fasting Glucose Or Impaired Glucose Tolerance. Epidemiology/Health Service/Psychosocial Research. Vol. 22. Pp. 399-402.

31. Simon, ND. Nicuolo, FD. Marzioni, D. Castellucci, M. Sanguinetti, M. D'lppolto, S. et al, 2009. Resistin modulates glucose uptake and glucose transporter-1 (GLUT1) expression in trophoblast cells. Blackwell Cellular and Molecular Medicine. Vol. 1, no. 2. pp. 388-397.

32. Un, JJ and Myung-Sook, C, 2015. Obesity And Its Metabolic complications: The Role Of Adipokines And The Relationship Between Obesity, Inflammation, Insulin Resistance, Dyslipidemia And Nonalcoholic Fatty Liver Disease. Center For Food And Nutritional Genomic Reserach. Vol. 15. pp. 6184-6223.

\section{BIOGRAPHY}

First Author The author is a lecturer at one of the Stikes in Pekanbaru city. Born on September 18, 1988. Graduated from the D4 Midwifery study in 2012 and completed a midwifery S2 study at Andalas University in 2018.

Second Author The author is a professor in the medical faculty of Andalas University.
33. Unwin, N. Shaw, J. Zimmet,P. Alberti, K.G, 2002. Impaired glucose tolerance and impaired fasting glycaemia: the current status on definition and intervention. International Diabetes Federation IGT/IFG Consensus Statement. Report of an Expert Consensus Workshop 1-4 August 2001, Stoke Poges, UK

34. Vernini, JM. Moreli, JB. Antonio, R. Negrato, CA. Cunha, MV. Caldero, IM, 2016. Maternal AdipokinesAnd Insulin As Biomakers Of Pregnancy Complicated By Overweight And Obesity. Diabetology\& Metabolic Syndrome. Vol. 8. Pp.68.

35. Viengsakhone, L. Yoshida, Y. OrRashid, H \& Sakamoto, J, 2010. "Factors Affecting Low Birth Weight" At Four Central Hospitals In Vientine, Lao Pdr, Journal Nagoya med Vol. 72, pp. 51-58.

36. Yuan, L. Cheng-Yuan, S. Shan-Shan,W. Qiu-Hua, L. Ling-Qing, Y. Er-Yuan,L, 2013. Novel AdipokinesAnd Bone Metabolism.

37. Yoshito, I. Hiroyuki, T. Susuma, H. Kazuaki, K and Kentaro, K, 2013. Resistin Affects Lipid Metabolism During Adipocyte Maturation Of 3T3-L1 Cells. Departments of Medicine And Oncological Sciences. Vol. 280.pp.58845895.

$\mathrm{He}$ is the head of the midwifery section in the Obstetrics Gynecology subdivision at M. Djamil Hospital, Padang.

Third Author Pediatrician in Dr. M. Djamil Padang, Emergency Child Hospitalization Division.Born in Batusangkar on May 28, 1958. In 2007 he continued his S3 study program at the Faculty of Medicine, AndalasUniversity. 